\title{
María profetisa en el Magnificat Aportes de hermenéutica bíblica feminista sobre Lc 1,46b-55
}

\author{
VIRGINIA R. AZCUY \\ Facultad de Teología \\ Pontificia Universidad Católica de Chile \\ razcuy@uc.cl \\ (D) https://orcid.org/0000-0001-5462-2065
}

Resumen: En la historia de la recepción reciente del Magnificat, se han destacado diversos aportes de la teología de la liberación, la teología feminista y la hermenéutica bíblica feminista. Este estudio se propone revalorizar las voces de autoras como Elizabeth A. Johnson, Mercedes Navarro Puerto, Ivoni Richter Reimer y Luise Schottroff -junto a las de otras/os exégetas de la obra lucana-, para explicitar su lectura crítica y renovadora en la comprensión de María. La hipótesis de este estudio afirma que diversos aportes del acercamiento feminista al Magnificat (Lc 46b-55) han contribuido a un redescubrimiento de la figura de María por medio de una memoria de su vocación como profetisa en solidaridad con las mujeres.

Palabras clave: Magnificat, María, mujer profetisa, solidaridad con las mujeres, hermenéutica bíblica feminista, mariología feminista, mujeres en el evangelio de Lucas.

Abstract: Several contributions from liberation theology, feminist theology, and feminist biblical hermeneutics have been highlighted throughout the history of recent reception of the Magnificat. The aim of this study is to reassess the value of the voices of women authors such as Elizabeth Johnson, Mercedes Navarro Puerto, Ivoni Richter Reimer, and Luise Schottroff, together with those of other Lucan exegetes, both women and men, to make their refreshing critical readings explicit within the understanding of Mary. The hypothesis guiding this study affirms that several contributions from the feminist approach to the Magnificat (Luke 46b-55) have aided in the rediscovery of Mary's image by focusing on her calling as a prophetess in solidarity with women.

Keywords: Magnificat, Mary, prophetess, solidarity with women, feminist biblical hermeneutics, feminist Mariology, women in St. Luke's Gospel. 
Ya hace algunas décadas, el reconocido exégeta alemán Norbert Lohfink afirmaba que, en nuestro tiempo, el Magnificat ha sido redescubierto, tanto por la teología de la liberación como por la teología feminista, como una especie de texto-base para diversas perspectivas teológicas ${ }^{1}$. Una obra insoslayable en el ámbito de la mariología de la liberación, que dedica una amplia atención al cántico del Magnificat en nuestro contexto, es sin duda la escrita por Clodovis Boff: Mariologia social. O significado da Virgem para a Sociedade ${ }^{2}$. El Magnificat, para este teólogo, puede entenderse como el canto de la liberación mesiánica y, por ello, como el locus biblicus maior de una mariología de la liberación ${ }^{3}$. En este mismo ámbito, se destaca también -entre las obras de referencia- el libro Verdadera hermana nuestra. Teología de María en la comunión de los santos, de la teóloga norteamericana Elizabeth A. Johnson ${ }^{4}$. En consonancia con la tendencia de la mariología posconciliar que busca renovarse desde la perspectiva bíblica, la autora ofrece una visión de conjunto de los testimonios bíblicos sobre María y afirma que "trazar los contornos de esta escena [la visitación] y su teología desde una perspectiva bíblica crítica y feminista aporta una tesela deslumbrante, inconfundiblemente profética al mosaico de la memoria crítica de María" 5 . Se podría decir entonces, sin temor a equivocarse, que el Magnificat representa el locus biblicus maior de una mariología feminista de la liberación que, en cuanto tal, se interesa directamente por la plena liberación de las mujeres.

En el ámbito de los estudios bíblicos, un balance de Marinella Perroni afirma que ya a finales de la década de los noventa el tema de las mujeres en la obra lucana se presentaba como un debate claramente establecido. Un buen número de estudios consideraban a Lucas como el "evangelista de las mujeres" y otro tanto valoraban como ambigua su posición en relación con ellas y su papel en la comunidad cristiana ${ }^{6}$. El estudio de G. W. Forbes - S. D. Harrower, dedicado a este mismo tema, confirma las dos posiciones principales: el

${ }^{1}$ Cf. N. LoHFINK, Lobgesänge der Armen. Studien zum Magnificat, den Hodajot von Qumran and einigen späten Psalmen (Stuttgarter Bibel-Studien 143; Katholisches Bibelwerk, Stuttgart 1990) 13.

2 C. M. Boff OSM, Mariologia social. O significado da Virgem para a Sociedade (Coleção Teologia Sistematica; Paulus, São Paulo 22009). Cf. J. C. REY GARCíA PAREDES, "Mariología social en Teología política", EphMar LXII (2012) 421-440, 427.

${ }^{3}$ Cf. C. M. Boff, Mariologia social, 311-380; C. M. BofF, "Por una mariología social”, Concilium 327 (2008) 51-64, 57.

${ }^{4}$ E. A. Johnson, Verdadera hermana nuestra. Teología de María en la comunión de los santos (Herder, Barcelona 2005). Cf. V. R. AzCuY, "Hablar rectamente de María. La hermenéutica feminista de Elizabeth A. Johnson”, en V. R. AzCuY - M. Garcia BACHMAnnC. LÉRTOR - A MENDOZA (coord.), Estudios de Autoras. En América Latina, el Caribe y Estados Unidos (Mujeres haciendo teologías 3; San Pablo, Buenos Aires 2009) 247-266.

${ }^{5}$ E. A. Johnson, Verdadera hermana nuestra, 301.

${ }^{6}$ Cf. M. Perroni, "Discípulas, pero no apóstoles en la obra de Lucas", en M. NAVArro - M. Perroni (eds.), Los Evangelios. Narraciones e historia (Editorial Verbo Divino, Estella 2011) 181-221, 181. 
acercamiento "general descriptivo positivo" como aporte contracultural y la visión "feminista-liberacionista", que considera restrictiva la eclesiología lucana desde la perspectiva de género ${ }^{7}$. En el primer grupo, se podrían mencionar -con matices- los comentarios y estudios de Raymond E. Brown, Josepf A. Fitzmyer, François Bovon, Joel B. Green y Rudolf Schnackenburg en torno a los años noventa y, entre las obras más recientes, a Ben Witherington, Darrell Bock y Richard Bauckham, según el panorama de Forbes-Harrower. En el segundo grupo, de especial interés en este artículo, se ubican primero diversos estudios feministas publicados en torno a la década del noventa, entre cuyas autoras se destacan los nombres de Mercedes Navarro Puerto, Jane Schaberg, Ivoni Richter Reimer, Luise Schottroff, Elisabeth Schüssler Fiorenza y Barbara Reid $^{8}$. Algunas de ellas vuelven a publicar en una segunda ola de producción y se agregan otras como Amy-Jill Levine, Elizabeth A. Johnson y Lina Boff 9 . Finalmente, cabe destacar la progresiva recepción de la perspectiva feminista y/o de sus aportes, con distintos matices y acentos, en algunos estudios y comentarios recientes sobre el evangelio de $\operatorname{Lucas}^{10}$.

El presente artículo se inscribe en el marco de este énfasis ginocéntrico que ha ido surgiendo en los estudios bíblicos. Asume la perspectiva metódica de la hermenéutica bíblica feminista como una crítica a la recepción predominantemente masculina de la Biblia y en cuanto tal valora las cartografías de los estudios bíblicos feministas e impulsa su desarrollo y florecimiento, según la comprensión de Elisabeth Schüssler Fiorenza ${ }^{11}$. En este

${ }^{7}$ Cf. G. W. Forbes - S. D. HARrower, Raised from Obscurity: A Narratival and Theological Study of the Characterization of Women in Luke-Acts (Pickwick, Eugene, OR 2015) 1-10. Véase la tercera aproximación en relación con Loretta Dornisch.

${ }^{8}$ Cf. M. Navarro Puerto, María, la mijer. Ensayo psicológico bíblico (Claretianas, Madrid 1987); J. SCHABERG, Illegitimacy of Jesus: A Feminist Theological Interpretation of the Infancy Narratives (Harper \& Row, San Francisco 1987); I. RichTER REIMER, Women in the Acts of the Apostles. A Feminist Liberation Perspective (Fortress Press, Minneapolis 1995), original alemán de 1992; L. SCHOTTROFF, Lydia's Impatient Sisters: A Feminist Social History of Early Christianity (Westminster John Knox Press, Louisville 1995), original alemán de 1994; E. SCHÜssLER FIORENZA, Cristología feminista crítica. Jesús, Hijo de Miriam, Profeta de la Sabiduria (Editorial Trotta, Madrid 2000), original inglés de 1994; B. REID, Choosing the Better Part? Women in the Gospel of Luke (Liturgical Press, Collegeville, Minneapolis 1996).

${ }^{9}$ Cf. E. A. Johnson, Verdadera hermana nuestra (original inglés de 2003); A.-J. LEvine (ed.), A Feminist Companion to Mariology (The Pilgrim Press; Cleveland 2005); L. BofF, Mariologia. Interpelações para a vida e para a fé (Editora Vozes; Petrópolis, RJ 2007); M. NAVARRO PUERTO, Los rostros bíblicos de María (Editorial Verbo Divino, Estella 2020).

10 A modo de ejemplo, véase G. W. FORBES - S. D. HARROwER, Raised from Obscurity; A.-J. Levine - B. Witherington III, The Gospel of Luke (New Cambridge Bible Commentary; Cambridge University Press, Cambridge/New York 2018).

11 Cf. E. SCHÜSsLer FIORENZA, "Entre la investigación y el movimiento social: estudios feministas de la Biblia en el siglo XX”, en E. SCHÜSSLER FIORENZA (ed.), La exégesis feminista del siglo XX (La Biblia y las Mujeres 20; Editorial Verbo Divino, Estella 2015) 15-32, 15 ss. 
sentido, se busca revalorizar las voces de algunas autoras como Elizabeth A. Johnson, Mercedes Navarro Puerto, Ivoni Richter Reimer y Luise Schottroff en vistas a revisitar el Magnificat desde la hermenéutica bíblica feminista. Como ha propuesto Phyllis Bird, lo que hace que una lectura feminista sea feminista es, precisamente, que haya "un/a lector/a feminista"12, es decir, una lectura como forma de producción literaria en la cual un texto bíblico sea interpretado para una cierta audiencia y una posición crítica y constructiva que busque un trato humano hacia las mujeres. Esta aproximación al texto es dialogal por cuanto considera tanto la producción del texto como su recepción y además busca respetar su integridad para realizar su hermenéutica. Desde la propuesta de Luise Schottroff, el acercamiento feminista se basa en reconocer el propio punto de vista y realizar una investigación crítica de las perspectivas no reconocidas en los textos existentes -tanto de autores como de intérpretes- ${ }^{13}$. Una lectura de estas características reviste suma importancia por cuanto, como ha indicado E. A. Johnson,

siglos de interpretación patriarcal han etiquetado la respuesta de María como obediencia sumisa y presentado esta postura como el ideal adecuado de mujer en la relación con el varón: una visión que está en contradicción con las esperanzas de la mujer en su propia dignidad ${ }^{14}$.

En este estudio se propone una aproximación a la figura de María como profetisa a partir de Lc 1,46b-55, en diálogo con los aportes de algunas autoras feministas de nuestro tiempo. Como la pretensión no puede ser exhaustiva, conviene delimitar de antemano las opciones y los límites de este texto, con la esperanza de poder ampliarlo en el futuro: 1. se focaliza en una lectura sincrónica del Magnificat a partir de una hermenéutica bíblica feminista, por considerarse prioritaria para superar el sesgo androcéntrico dominante en los textos y sus intérpretes; 2 . se recuperan también algunos elementos de una lectura diacrónica del escrito, en función del argumento central, quedando pendiente su profundización; 3. se destaca un interés principalmente mariológico, sin desconocer la primacía de la cristología en los ciclos de anuncio y nacimiento, ni la conexión de la figura mariana con las mujeres en

\footnotetext{
${ }^{12}$ Cf. P. A. BIRD, "What makes a Feminist Reading Feminist? A Qualified Answer", en H. C. Washington; S. Lochrie Graham; P. Thimmes (eds.), Escaping Eden: New Feminist Perspectives on the Bible (Sheffield Academic Press, Sheffield 1998, 124-131, 125; A. PILARSKI, "Una transversal en el pensamiento de Phyllis Bird. Pasos hacia una hermenéutica bíblica feminista”, en V. R. AZCuY - M. GARCiA BACHMANN - C. LÉRTORA MENDOZA (coord.), Estudios de Autoras, 115-133, 122s.

${ }^{13}$ Cf. L. SCHOTTROFF, "Introduction", en I. RiCHTER REIMER, Women in the Acts of the Apostles, XI-XIV, XII.

${ }^{14}$ E. A. JOHNSON, Verdadera hermana nuestra, 296.
} 
un horizonte eclesiológico, en la doble obra lucana ${ }^{15} ; 4$. se elige privilegiar una lectura del himno del Magnificat en relación con los episodios de la anunciación y la visitación en los relatos de infancia (Lc 1,5 - 2,52); 5. se opta por una recuperación de la figura de María como profetisa en solidaridad con las mujeres, ante todo en relación con Isabel $(1,5-25)$ y la solidaridad entre ellas $(1,39-45)$, en el horizonte de la tradición judía de mujeres humilladas y exaltadas por Dios, según las perspectivas abiertas por Luise Schottroff ${ }^{16}$. Asimismo, el desarrollo se presenta dedicado al himno, en relación con su contexto y su estructura. Por otra parte, se propone una lectura de la voz de Mariám y su figura de profetisa en solidaridad con las mujeres en Lc 1,46b-55, y por último, una parte conclusiva expone breves reflexiones finales y señala algunas perspectivas abiertas para continuar la investigación.

\section{EL HIMNO DEL MAGNIFICAT}

\subsection{Traducción de Le 1,46b-55}

46b Proclama mi alma la grandeza del Señor,

${ }^{47}$ mi espíritu se alegra en Dios, mi Salvador,

${ }^{48}$ porque miró la humillación de su sierva ${ }^{17}$.

Desde ahora me llamarán feliz todas las generaciones.

${ }^{49}$ Porque el Poderoso hizo grandes cosas en mí.

Santo es su Nombre ${ }^{18}$,

${ }^{50} \mathrm{Y}$ su misericordia llega

de generación en generación

para aquellos que lo temen.

${ }^{51}$ Ejerció la fuerza de su brazo,

dispersó a los soberbios de corazón.

${ }^{52}$ Bajó a los poderosos de su trono

y levantó a los humildes.

\footnotetext{
15 Un balance sobre el sesgo patriarcal o la ambigüedad de la obra lucana con respecto a las mujeres, con especial atención a la eclesiología, no es posible en este estudio. Cf. M. PERronI, "Discípulas, pero no apóstoles en la obra de Lucas", 182ss; B. REID, “The Gospel of Luke: Friend or Foe of Women Proclaimers of the World", The Catholic Biblical Quarterly 78 (2016) 1-23.

16 Se sigue y continúa, en este estudio, el camino propuesto por L. SCHOTTROFF, Lydia's Impatient Sisters, $177 \mathrm{ss}$.

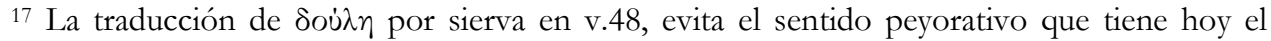
significado literal de "esclava" y la vincula con la alusión al vocablo $\pi \alpha i ̄ \varsigma$ referido a Israel en v.54. Cf. E. A. JOHNSON, Verdadera hermana nuestra, 296-297.

18 Resulta interesante la variante de iniciar el v.50 con esta oración en la traducción ofrecida por L. Alonso SCHÖKEL - J. MATEOS, Salmos y Cánticos del Breviario (Ediciones Cristiandad, Madrid ${ }^{71987)} 475$.
} 
${ }^{53}$ A los hambrientos los llenó de bienes

y a los ricos los echó vacíos.

54 Auxilió a Israel, su siervo,

acordándose de la misericordia,

${ }^{55}$ Como lo había prometido a nuestros padres,

en favor de Abraham y su descendencia para siempre.

\subsection{Ubicación del bimno en los ciclos de anuncio y nacimiento}

\subsubsection{La estructura de Lc 1,5 - 2,52 (relato de infancia)}

El texto lucano de la infancia, que se presenta en la forma de ciclos de anuncio y nacimiento, se destaca como bloque dentro del material propio del tercer evangelio y se comprende en el horizonte de las antiguas biografías, en las que se distinguían los orígenes, la vida pública y la muerte del protagonista ${ }^{19}$. En el relato de anuncio y nacimiento (Lc 1,5 - 2,52) se distingue en primer lugar, su estilo característico que consiste en imitar la traducción griega del Antiguo Testamento (Septuaginta) ${ }^{20}$. El género empleado es el de la historiografía imitativa e indica que los materiales históricos utilizados en el relato fueron objeto de una profunda elaboración personal, con la finalidad de moldearlos a imitación de otros relatos bíblicos del Antiguo Testamento como sucede, en Lucas, con la narración del nacimiento y los primeros años de Samuel (1S 1-3)- ${ }^{21}$. El segundo elemento distintivo es la presencia de varios himnos que reflejan una teología judeocristiana muy antigua y material narrativo que asume temas característicos de la teología lucana, como la llegada de la salvación y la identificación de Jesús con el Salvador ${ }^{22}$.

El relato se estructura sobre la base de un estrecho paralelismo entre Juan, el Bautista, y Jesús, el Mesías, dispuesto en alternativa sucesión, con la finalidad de mostrar la superioridad del Mesías ${ }^{23}$. Se habla de una organización interna

${ }^{19}$ Cf. S. Gujarro, Los cuatro evangelios (Colección Biblioteca de Estudios Bíblicos; Ediciones Sígueme, Salamanca ${ }^{32016)} 366$.

${ }^{20}$ Cf. S. Guijarro, Los cuatro evangelios, 361.

${ }^{21}$ Cf. J. A. Fitzmyer, El evangelio según San Lucas. II. Traducción y Comentario de 1-8,21 (Ediciones Cristiandad, Madrid 1987) 50; F. BovON, El Evangelio según San Lucas I (Lc 1,1-950) (Ediciones Sígueme, Salamanca 2005) 71.

22 Cf. S. Guijarro, Los cuatro evangelios, 361; F. Bovon, El Evangelio según San Lucas I, 42; J. B. GreEN, The Gospel of Luke (The New International Commentary on the New Testament; Eerdmans Publishing Company, Grand Rapids, Michigan / Cambridge, UK 1997) 21ss.

23 Cf. R. E. Brown, El nacimiento del Mesías. Comentario a los Relatos de la Infancia (Ediciones Cristiandad, Madrid 1982) 253ss; J. A. FITZMYER, El evangelio según San Lucas II, 57-62; F. BOvOn, El Evangelio según San Lucas I, 68-75; I. GÓMEZ ACEBO, Lucas (Desclée de Brouwer, Bilbao 2008) 27-28; J. B. GreEn, The Gospel of Luke, 50ss; D. L. BOCK, Luke (Baker Exegetical Commentary on the New Testament 3A; Baker Publishing Group, Grand Rapids, Michigan 
que contiene dos anuncios de nacimiento y dos nacimientos, conformada por dos dípticos: el anuncio sobre Juan Bautista (Lc 1,5-25); el anuncio sobre Jesús (1,26-38); el relato sobre el Bautista (1,57-66.80) y el relato sobre Jesús (2,1-27.34-40). A estos dípticos, se añaden otros siete o seis episodios, conforme se distinga entre los relatos de la presentación en el templo y Jesús hallado en el templo. En este estudio, se adopta la división en seis episodios, organizados en dos dípticos, por constituir estos la espina dorsal del conjunto y un episodio complementario para cada díptico ${ }^{24}$. También, se añade la inclusión de cuatro himnos -tres de ellos mayores-, que apuntan a Jesús. Estos himnos, en labios de María, Zacarías, los ángeles y Simeón, hacen más compleja la estructura del relato sin privarlo de armonía y dándole una particular atmósfera de alegría, semejante a la presentada en Hch 2, que anuncia la intervención de Dios entre cánticos ${ }^{25}$.

Primer diptico

Anuncio sobre Juan Bautista: 1,5-25

Anuncio sobre Jesús: 1,26-38

Episodio complementario 1

Encuentro de María e Isabel: 1,39-56

Viaje y visita: $1,39-46 a$

Himno: Magnificat: 1,46b-55

Regreso: 1,56

Segundo díptico

Nacimiento de Juan, el Bautista: 1,57-80

Nacimiento: $1,57-66$

Recibimiento: 1,67-80 (Benedictus: 68-79)

Nacimiento de Jesús, el Mesías: 2,1-40

Nacimiento: 2,1-21 (Gloria in excelsis: 13-14)

Recibimiento: 2,22-40 (Nunc dimittis: 29-32)

Episodio complementario 2

Jesús en el templo: 2,41-52

Los cuatro himnos que aparecen en los relatos de nacimiento - uno de ellos muy breve- reflejan una teología judeocristiana muy antigua $\mathrm{y}$, a la vez, un material narrativo construido sobre temas muy característicos del evangelio.

52004) 58ss; M. C. PARSONS, Luke (Paideia: Commentaries on the New Testament; Grand Rapids, Michigan 2015) 40.

${ }^{24}$ Cf. R. E. Brown, El nacimiento del Mesías, 257; J. A. FITZMYER, El evangelio según San Lucas II, 59; F. Bovon, El Evangelio según San Lucas I, 73, quien sigue la propuesta de W. Wink; S. GuijARro, Los cuatro evangelios, 372-373.

25 Cf. R. E. Brown y OTROS, María en el Nuevo Testamento. Una evaluación conjunta de estudiosos católicos y protestantes (Biblioteca de Estudios Bíblicos 49; Ediciones Sígueme, Salamanca 1986) 110; F. BovON, El Evangelio según San Lucas I, 71-72. 
Lucas podría haber compuesto un relato para poner un marco narrativo a estos himnos, aunque también puede tratarse de la reelaboración de un material preexistente o, incluso, imitar el estilo de salmos e himnos del Antiguo Testamento ${ }^{26}$. En efecto, en la tarea de composición de estos relatos, se cree que el evangelista utilizó otra clase de materiales, además de la primitiva tradición cristiana. Aunque resulta difícil identificarlos, suele admitirse una fuente judeocristiana, de donde procederían los tres cánticos - Magnificat (Lc 1,46-55), Benedictus (Lc 1,67-79) y tal vez el Nunc dimittis (Lc 2,29-32)- ${ }^{27}$. En el caso del Magnificat y el Benedictus, incluso podría tratarse de una tradición anterior, atestiguada en la literatura del $200 \mathrm{aC}$ al $100 \mathrm{dC}$, muy cercana a la teología de los primeros grupos judeocristianos de Jerusalén, que indicaría su surgimiento en una comunidad judeocristiana como la de Qumrán, con la piedad de los anawim $^{28}$. Esta religiosidad corresponde a un título que originalmente pudo designar a los pobres en sentido material, pero que luego pasó a caracterizar a quienes confían en Dios, no pudiendo apoyarse en sus propias fuerzas $^{29}$. N. Lohfink propone un estudio sobre el Magnificat, junto al libro canónico de los salmos y al libro de cantos del Qumrán -entre otros-, como un ejemplo típico de esta piedad de los pobres ${ }^{30}$. El autor habla del Magnificat como un testimonio de la piedad de los pobres porque la orante se entiende a sí misma como pobre y a Dios, a cuya alabanza ella asiente, lo reconoce como el que ayuda a los pobres. También lo observa como una obra de arte lingüística, que no responde a una poesía espontánea o instantánea, sino a una elaboración esmerada al modo de un poema antológico, a partir de diversas formulaciones de textos canónicos como los salmos y los profetas.

\subsubsection{Estructura 1,26-56 (anunciación y visitación)}

Los episodios del anuncio del nacimiento de Jesús $(1,26-38)$ y de la visita a Isabel con el Magnificat (1,39-56) tienen a María como protagonista y están presentados en función del nacimiento del Mesías. Ambos relatos sobre la vocación de María y su encuentro con Isabel sirven para presentar su identidad como Mesías dinástico que heredará el trono de David. En el diálogo con el ángel se devela lo que está implícito en la concepción virginal de María: que

${ }^{26}$ Así lo propone, por ejemplo, S. GUIJARRO, Los cuatro evangelios, 361.

${ }^{27}$ Cf. J. A. Fitzmyer, El evangelio según San Lucas II, 51; S. GUIJARro, Los cuatro evangelios, 371. Estos autores sostienen una fuente común; otros señalan una distinta proveniencia para los tres himnos, véase F. BOVON, El Evangelio según San Lucas I, 38.

28 Cf. N. Lohfink, Lobgesänge der Armen, 13-14; E. PeretTo, Voz "Magnificat", en S. DE FIORES - S. MEO (dir.), Nuevo Diccionario de Mariología (San Pablo, Madrid 1988) 1224-1237, 1225; S. GujJarro, Los cuatro evangelios, 371.

${ }^{29}$ Cf. R. E. Brown, El nacimiento del Mesías, 364ss; J. A. FitZMYER, El evangelio según san Lucas II, 141-142.

${ }^{30}$ Cf. N. LoHFInK, Lobgesänge der Armen, 13. 
Jesús es el Hijo de Dios ${ }^{31}$. Vale la pena observar la estructura de estas dos unidades narrativas en relación con los textos y episodios más significativos del Antiguo Testamento a los cuales recurre Lucas para elaborar su figura de María, sin olvidar que ella se orienta a precisar el destino de Jesús más que a construir una mariología ${ }^{32}$. Desde el punto de vista de la interfiguralidad, cabe destacar ante todo que el evangelista da a María el nombre de Mariám, que es la forma griega del hebreo Miryam como aparece en Nm 12 y que puede interpretarse como una asociación entre ambas mujeres ${ }^{33}$. Otra figura que asume Lucas sin mencionarla de forma explícita es la de hija de Sión de los profetas, al proponer a María como su actualización en relación con So 3,15-1734. En la misma perspectiva interfigural, María es tipificada como contraparte de Ana (1S 2,1-10), porque fragmentos de su oración inspiran el Magnificat, sobre todo en la inversión de situaciones (1S 2,4-8) y porque Ana, como María, se entiende a sí misma como "sierva del Señor" (1S 1,11; Lc 1,38) $)^{35}$. Sin embargo, es común -aunque tal vez no tan frecuente- la posición que destaca que son las tradiciones davídicas las que ofrecen el trasfondo mayor del cántico de María, especialmente el relato de la traslación del Arca a Jerusalén y el de la Alianza de Dios con David, actualizada en la anunciación (2S 7; Lc 1,32s. y 2,4.11) ${ }^{36}$. De este modo, según el evangelista, Mariám no sólo era la realización escatológica de Jerusalén, sino también el "nuevo David" de quien iba a salir el Mesías hijo de David. En efecto, algunos exégetas proponen que ella está más tipificada por la oración de David en 2S 7,18-29 que por la de Ana en 1S 2,1-10, como modelo davídico en función de la cristología, como lo sugiere Lc 1,32 $2^{37}$.

${ }^{31}$ Cf. S. Gujuarro, Los cuatro evangelios, 372.

32 Como estudio de referencia se sigue, en este punto, a S. CROATTO, "La «hija de Sión» en Lc 1-2. La imitatio y la interfiguralidad tipológica en la narrativa lucana", RIBLA 46 (2003) 1731.

${ }^{33}$ En general, se admite un nexo entre el Magnificat y el cántico de Ex 15,1-18 (Moisés) y 20-21 (Miriam); las exégetas feministas discuten la autoría del himno y lo atribuyen originariamente a Miriam, en razón del testimonio de Nm 12. Cf. M. GARCía BACHMANN, "Miriam. Figura política de primer plano en el Éxodo", en M. NAVARRO - I. FISCHER (eds.), La Torah (La Biblia y las Mujeres 1; Editorial Verbo Divino, Madrid 2010) 337-378.

${ }^{34}$ Cf. S. Croatto, "La «hija de Sión» en Lc 1 - 2", 23ss; M. NAVArRo Puerto, Los rostros bíblicos de María, 201.

35 Algunos exégetas han hablado del Cántico de Ana como "modelo" del Magnificat. Cf. R. E. Brown, El nacimiento del Mesías, 377; T. CARroll, Luke. A Commentary (Westminster John Knox Press, Louisville, Kentuky 2012) 47. Otros, en cambio, hablan de diversos modelos: véase por ejemplo a F. BOvON, El Evangelio según San Lucas I, 120ss; M. WOLTER, The Gospel according to Luke I (1-9:50) (Baylor University Press, Mohr Siebeck 2017) 91.

36 Cf. S. Croatto, "La anunciación a la luz de la teología de la alianza. María como antitipo de David”, Revista Bíblica 54, N 47 (1992) 129-139.

${ }^{37}$ Cf. R. E. Brown, El nacimiento del Mesías, 358s; S. Croatto, "La «hija de Sión» en Lc 1-2", 29 y G. W. FORBES - S. D. HARROWER, Raised from Obscurity, 49-50. 
En cuanto al género del relato del anuncio sobre Jesús (Lc 1,26-38), se piensa que Lucas fusiona un texto de anuncio con otro de vocación y misión de un profeta ${ }^{38}$. Mercedes Navarro refiere como ejemplos el caso de la historia de Moisés en Ex 3,1-14 y de Gedeón en Jue 6,11-24 ${ }^{39}$. De este modo, el relato queda orientado al mismo tiempo a la identidad de Jesús y a la misión profética de María por la acción del Espíritu.

Anuncio sobre Jesús: 1,26-38

Presentación de Mariám y José: 1,26-27 (Nm 12; Mt 1,18-25)

Entrada del ángel Gabriel: 1,28a

Primera sección, saludo: $1,28 \mathrm{~b}-29$

Saludo del ángel: 1,28b (Zac 9,9; Sof 3,14; J1 2,21: hija de Sión)

Reacción cognitiva emotiva de María: 1,29

Segunda sección, anuncio: 1,30-34

Anuncio del ángel: 1,30-33 (1S 1,18; 2S 7,8-16: Mesías davídico)

Reacción inquisitiva de María: 1,34

Tercera sección, promesa: 1,35-38

Promesa del ángel: 1,35 (Ex 40,35; 1S 16,13; Sl 91,4; Mt 1,18.20)

Signo: $1,36(1,24.41 \mathrm{ss})$

Reacción asertiva de María: 1,38 (1S 1,11)

Salida del ángel Gabriel: 1,38b

Encuentro de María e Isabel: 1,39-56

Viaje y visita: 1,39-46a (2S 6,1-11: traslado del arca)

Partida hacia Judá $(1,39 ; 2 S$ 6,2)

Entrada de María: 1,40 (saludo)

Primera sección, encuentro: 1,41

Saludo de María: 1,41 (Isabel, llena del Espíritu Santo)

Segunda sección, alabanza de Isabel: 1,42-45

Primera bendición: 1,42 (Jc 5,24; Jdt 13,18)

Confesión cristológica: 1,43 (2S 6,9: traslado del arca)

La voz de Mariám: 1,44

Segunda bendición: 1,45 (11,27-28)

Tercera sección, Magnificat: 1,46b-55 (1S 2,1-10: cántico de Ana; 2S 7,18ss)

Inversión de destino personal: 1,48 $(1,25)$

Inversión de destino comunitaria: 1,52-53

Salida de María, regreso: 1,56 (2S 6,11: traslado del arca)

\footnotetext{
38 Véase, por ejemplo, la posición de I. DE LA POTTERIE, María en el misterio de la Alianz̧a (BAC, Madrid 1993) 36ss; E. A. Johnson, Verdadera hermana nuestra, 290-292; B. E. REID, "An Overture to the Gospel of Luke", Currents in Theology and Mission 39,6 (2012) 428-434, 428429; I. Richter Reimer, "María en los evangelios sinópticos", 40; A.-J. Levine - B. WiTHERINGTON III, The Gospel of Luke, 43.

${ }^{39}$ Cf. B. E. REID, "An Overture to the Gospel of Luke”, 428ss; M. Navarro Puerto, Los rostros bíblicos de María, 197.
} 
En función de la lectura de este estudio, se destacan algunos elementos: la referencia fugaz a José -en comparación con la atención dada a Zacarías en el primer anuncio sobre Juan, el Bautista-; las entradas y salidas del ángel Gabriel y de María en la casa de Zacarías representan, como sucede en la Biblia hebrea, una transformación de la realidad humana ${ }^{40}$; en la anunciación se destaca el

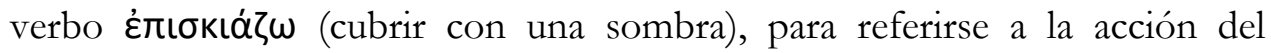
Espíritu, cuya presencia es también explícita en el episodio de la visitación, manifestando el tono profético del texto ${ }^{41}$; el canto del Magnificat es el primer himno del relato de infancia lucano y está pronunciado por una mujer. El himno pronunciado por María cumple una función hermenéutica para la comprensión del conjunto, dado que un material sacado de la tradición se presta a tal objetivo ${ }^{42}$. Esta función es primeramente cristológica y puede percibirse con claridad en una lectura conjunta de los dos episodios considerados en esta subsección: Jesús es el mesías davídico (1,32), María es su madre $(1,43)$ y por eso es y será llamada "feliz" $(1,45.48 \mathrm{~b})$. El anuncio sobre Jesús y la visita a Isabel han sido determinantes en la configuración de la teología y el culto a María a lo largo de los siglos y su lectura masculinamayoritaria ha planteado diversos interrogantes a la interpretación feminista de la Biblia en las últimas décadas. Entre ellos, la cuestión de si el Magnificat podría ejercer una función hermenéutica con respecto al lugar de las mujeres en la comunidad eclesial de la obra lucana ${ }^{43}$.

\subsection{Contexto y delimitación}

El contexto inmediato del Magnificat está dado por la escena de la visitación (Lc 1,39-45.56). Con el encuentro entre las dos mujeres protagonistas de los anuncios, Lucas enlaza la tradición del Bautista con la de Jesús ${ }^{44}$. Una cita de Elizabeth Johnson nos guía hacia la experiencia compartida:

El derramamiento del Espíritu sobre Isabel y María acaece en el espacio doméstico tradicionalmente femenino. Mujeres son los actores que ocupan el centro; mujeres las que toman la palabra para transmitir con fuerza la buena nueva que resuena; mujeres, también, las que encarnan la misericordia de Dios

\footnotetext{
${ }^{40}$ Cf. M. Navarro Puerto, Los rostros bíblicos de María, 199.

${ }^{41}$ Cf. R. E. Brown, El nacimiento del Mesías, 263-341; E. A. JoHnson, Verdadera hermana nuestra, 288-318.

42 Cf. F. Bovon, El Evangelio según San Lucas I, 72-74.

${ }^{43}$ Cf. C. JANSSEN - R. LAMB, "Das Evangelium nach Lukas. Die Erniedrigten werden erhöht", en L. SCHOTTROFF - M.-TH. WACKER (eds.), Kompendium Feministische Bibelauslegung (Chr. Kaiser Gütersloher Verlags, Gütersloh 21998) 513-526, 517.

${ }^{44}$ Cf. F. Bovon, El Evangelio según San Lucas I, 119-120; S. GuIjARro, Los cuatro evangelios, 372ss.
} 
que ellas mismas proclaman. Y actúan así en el contexto de un encuentro y afirmándose la una a la otra ${ }^{45}$.

En el episodio de la visitación, el espacio del encuentro es la casa de Zacarías

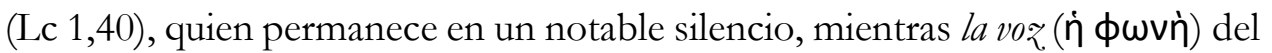
saludo de María $(1,40.44)$ pone en marcha la dinámica espiritual del encuentro. Como apunta Mercedes Navarro, en esta ocasión se inaugura el espacio doméstico como ámbito en el cual se proclama el evangelio. Así, la casa se convierte en lugar del Espíritu, que llega a una mujer -Isabel, llena del Espíritu Santo- por la presencia de otra mujer que porta en su cuerpo el comienzo de una nueva casa y una nueva genealogía, ambas inclusivas ${ }^{46}$. En su lectura de la escena, Ivoni Richter Reimer ha destacado que "el protagonismo de las mujeres es el elemento fundamental de esta historia" y sus "dos cuerpos grávidos y solidarios" son la fuente que hace brotar alabanza y confesión ${ }^{47}$. Isabel y María comparten sus experiencias y se dan apoyo mutuamente, resume Bovon, al afirmar que el "reconocimiento mutuo de su maternidad confiere a cada una de las dos mujeres una dignidad mayor" ${ }^{48}$. Éstas toman la palabra y pronuncian su alabanza. Isabel profiere una bendición y una bienaventuranza para alabar a María, quien en reacción dirige su alabanza a Dios. Sin desconocer la atribución del Magnificat a María, las autoras concuerdan en la unidad entre ambas mujeres: "el abrazo afectuoso, cuerpo a cuerpo"; "un canto común", enraizado en la relación ${ }^{49}$.

Los versículos 39-41 introducen el himno pronunciado por Isabel en la visitación y contienen algunos detalles característicos: la acción de María en v.39, indicada con el participio aoristo en femenino ávaotás (habiéndose levantado o puesto de pie), de ávíotn $\mu \mathrm{l}$, que algunos han asociado a su obediencia, mientras otras/os a su decisión libre impulsada por el Espíritu ${ }^{50}$; la

\footnotetext{
${ }^{45}$ E. A. Johnson, Verdadera hermana nuestra, 302.

${ }^{46}$ Cf. M. Navarro Puerto, "De casa en casa: las mujeres en la Iglesia doméstica lucana", Reseña bíblica 14 (1997) 35-44.

47 I. RiCHTER REIMER, "Lucas 1-2 bajo una perspectiva feminista ...y la salvación se hace cuerpo", RIBLA 44 (2003) 32-52, 33.52. En sentido semejante, C. NAVIA VELASCO, "María e Isabel, diálogo entre mujeres", RIBLA 46 (2003) 9-16; A.-J. LEVINE - B. WiTHERINGTON III, The Gospel of Luke, 38; J. B. GREEN, The Gospel of Luke, 92.

${ }^{48}$ F. BovOn, El Evangelio según San Lucas I, 120. Cf. E. A. JOHNSON, Verdadera hermana nuestra, 302-303.

49 I. Richter ReIMER, "María en los evangelios sinópticos. Una historia que se sigue escribiendo", RIBLA 46 (2003) 32-46, 41; C. JANSSEN - R. LAMB, "Das Evangelium nach Lukas", 519.

50 Asocia a obediencia: R. E. Brown, El nacimiento del Mesías, 345.355ss; enfatizan la decisión, la agencia y la libertad: I. RICHTER REIMER, "Lucas 1-2 bajo una perspectiva feminista", 33ss; G. W. FORBES - S. D. HARROWER, Raised from Obscurity, 50; A.-J. LEVINE - B. WiTHERINGTON III, The Gospel of Luke, 39; M. NAVARro PUERTO, Los rostros bíblicos de María, 208.
} 
casa de Zacarías en v.40, que recuerda su falta de fe, su estado de mudez y los gritos de alegría de Isabel, que algunos escribas intentaron corregir por voz, para moderar la escena; la figura profética de Isabel, llena del Espíritu Santo en v.41, como indicador de la promesa ya cumplida ${ }^{51}$. Un elemento que pocos autores/as han destacado y que merece ser recuperado -en estos versículoses la entrada de María en la casa de Zacarías y su saludo (vv.40-41), que es evocado en medio de la bendición de Isabel: "apenas oyó la voz de tu saludo" (v.44), para señalar los efectos de la voz del saludo de María ${ }^{52}$. Su voz da a conocer la presencia del Señor en sus entrañas -como en la tradición del arca de la alianza-: "lo importante es el hablar de María" 53 . Sin entrar en la discusión sobre la aplicación de la figura del arca a María ${ }^{54}$, queda planteado el tema de su voz en el saludo, pues en ella puede verse reflejada una señal de la función profética de María, que anticipa su alabanza en el Magnificat.

La alabanza de Isabel se encuentra en los versículos $42 \mathrm{~b}-45$ y puede dividirse en la bendición (v.42), el encuentro entre las mujeres (vv.43-44) y la bienaventuranza (v.45). La primera fase se expresa con un participio pasivo en

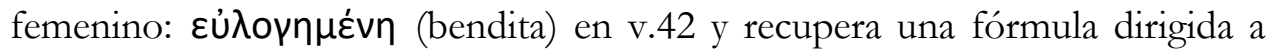
mujeres famosas en la historia de Israel -Jael (Jc 5,24) y Judit (Jdt 13,18)-, con lo cual se afirma que María tiene una función en el plan de salvación, sin afirmarse que es la única ${ }^{55}$. Dicho en positivo, María se encuentra "entre las mujeres" que han tenido un papel decisivo en el plan salvífico de Dios y como "prototipo de los nuevos cristianos" 56 . En este sentido, Elizabeth Johnson comenta que "la exuberante alabanza de Isabel, pronunciada con una alegría irrefrenada, pone a María en solidaridad con una larga herencia de mujeres, cuya actuación creativa, emprendida con el poder del Espíritu, trae la liberación en nombre de Dios" ${ }^{57}$. El encuentro entre las mujeres, que ya ha comenzado con la entrada y el saludo de María (v.40), se profundiza en los vv.43-44 que dan lugar para la admiración y el reconocimiento de Isabel por la visita de su prima. La bienaventuranza proclamada por Isabel sobre María, en v.45, es la primera del evangelio de Lucas y está dirigida a una mujer; en ella, se utiliza el

${ }^{51}$ Cf. F. Bovon, El Evangelio según San Lucas I, 127; J. B. GreEn, The Gospel of Luke, 93.

${ }^{52}$ Cf. I. Richter Reimer, "Lucas 1-2 bajo una perspectiva feminista", 51.

53 G. ARANDA PEREZ, "La visitación: el arca nuevamente en camino (Lc 1,39-45.56)", en A. ApARICIO Rodríguez (ed.), María del Evangelio. Las primeras generaciones cristianas hablan de Maria (Publicaciones Claretianas, Madrid 1994) 177-207, 191.

${ }^{54}$ Bajo la perspectiva de la interfiguralidad, S. Croatto propone a María como anti-tipo de

David y relaciona a ambos con el arca de la alianza. Cf. S. CroftTo, "La «hija de Sión» en Lc 1-2", 24ss.

55 Cf. R. E. Brown y otros, María en el Nuevo Testamento, 136; E. A. JohnSon, Verdadera bermana nuestra, 304.

56 I. GÓMEZ ACEBO, Lucas, 46.

${ }^{57}$ E. A. JoHnSON, Verdadera hermana nuestra, 304. 
adjetivo en femenino $\mu \alpha \kappa \alpha \rho i ́ \alpha$ (feliz), que indica un estado previo de felicidad o bendición; el macarismo se repite en el Magnificat, con el anuncio de una alabanza futura dirigida hacia María (v.48), en las bienaventuranzas (Lc 6,2022) y luego con ocasión del valor de la fe, dirigiéndose nuevamente a María en 11,27-28. La importancia de la segunda alabanza pronunciada por Isabel se relaciona ante todo con la inclusión de María entre las bienaventuranzas lucanas: ella es la primera en actuar como discípula en razón de su fe $(\operatorname{Lc} 1,38)^{58}$ у al llamarla $\mu \alpha \kappa \alpha \rho i \alpha$, Lucas la ubica junto a las tradiciones más antiguas sobre Jesús de Nazareth, como las bienaventuranzas y el grupo de los pobres ${ }^{59}$.

Al revisar la delimitación del himno del Magnificat (Lc 1,46b-55), conviene

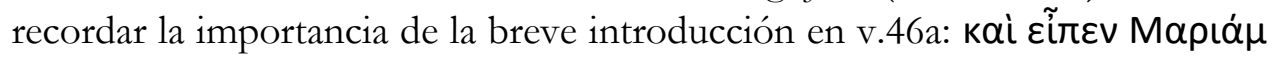
(y dijo María), que repite casi de manera exacta -en el texto griego- el introito a las palabras de María en respuesta al anuncio del ángel Gabriel $(1,38)$. El enlace entre los dos episodios queda en evidencia mediante la referencia a ella como "sierva del Señor" (1,38.48) y otros detalles (cf. 1,35 y 49a; 1,38 y 45), dejándose ver al mismo tiempo que ella es un sujeto que tiene voz y la pronuncia en los momentos determinantes. Con respecto a sus palabras en la anunciación, se ha indicado a la luz de los relatos paralelos de anuncio en el Antiguo Testamento que no es frecuente un consentimiento formulado tan explícitamente, lo que abona la comprensión de este relato según un esquema literario de alianza ${ }^{60}$. La función directa del v.46a es la de poner el canto de alabanza y la acción de gracias en labios de María. Si bien casi todos los manuscritos griegos y las antiguas versiones lo asignan a ella, tres escritos latinos abren la posibilidad de una atribución del himno a Isabel ${ }^{61}$. No obstante,

${ }^{58}$ Cf. R. E. Brown y OTros, María en el Nuevo Testamento, 137.

59 Cf. L. Schottroff, "Magnificat und die älteste Tradition über Jesus von Nazareth", Evangelische Theologie 38 (1978) 298-313, 298ss.

${ }^{60}$ Cf. F. Bovon, El Evangelio según San Lucas I, 117; A. SERRA, Voz "Biblia/Lucas", en NDM 300-385, 314-315.

${ }^{61}$ Los manuscritos de la Vetus Latina a, b, 1*, datables entre los siglos IV y VIII; los manuscritos latinos $\mathrm{C}, \mathrm{V}$, la versión armenia de $A d v$. Haer. IV, 7,1 de Ireneo -independiente de la versión latina de Lc 1,46 y dependiente de la siriaca, pero en contradicción con Adv. Haer. III, 10,2-, así como Nicetas de Remesiana, localidad cercana a la antigua Nassus -la actual Nisch de Serbia-, en De Psalmodiae Bono IX,11, escrito hacia el 400. Con respecto a la traducción de Orígenes hecha por Jerónimo, In Lucam Homiliae, 7 (PL 26:247), se cree que la atribución puede venir de Jerónimo y no de Orígenes y que este podría haber sido testigo de tal atribución del cántico a Isabel sin compartirla. Cf. E. Y E. NESTLE - K. AlAND, Novum Testamentum Graece (Deutsche Bibelgesellschaft, Stuttgart 282014 , tercera impresión corregida de la $28^{\circ}$ edición revisada) 180 . 
el peso de la tradición resuelve la cuestión a favor de una atribución del himno a María por parte de Lucas $^{62}$.

Dado que el núcleo del himno trata sobre la inversión escatológica, por medio de su atribución a María, Lucas la hace portavoz de "una parte vital del mensaje evangélico", alguna en considerar a una mujer como intérprete autorizada de las Sagradas Escrituras y de su propio tiempo, como ya lo había hecho -en menor medidaen el caso de Isabel ${ }^{64}$.

Al finalizar el himno, se observa una reanudación y cierre de la narración en prosa en v.56: "María permaneció con Isabel unos tres meses y luego regresó a su casa". La delimitación del himno es clara, por el género poético y por el sujeto que toma la palabra. Los estudiosos agregan, además, que el cántico del Magnificat es notablemente más poético que el relato de la visitación y el cántico de Isabel, lo cual abona -para el himno atribuido a María- la idea de un texto muy elaborado ${ }^{65}$. En cuanto al v.56, se destaca como espacio la casa de María: ella que había viajado sola, sin José, ahora regresa a su propia casa, no a la de él ${ }^{66}$.

\subsection{Estructura del Magnificat}

El Magnificat presenta características muy semejantes a los salmos e himnos qumránicos, en concreto a las Hodayot que son himnos de acción de gracias en los cuales el orante se identifica como uno de los anawim y alaba a Dios por sus obras. Este género se caracteriza, en general, por seguir un esquema tripartito con una breve introducción que contiene el deseo de alabar a Dios; el cuerpo del himno con los motivos de la alabanza, introducidos muchas veces con una oración causal con ötı, para considerar las acciones de Dios y sus atributos; y una conclusión, menos definida, que puede recapitular los motivos o incluir una bendición o petición. En el caso del Magnificat, se habla de un poema antológico o bimno narrativo que utiliza formulaciones de textos canónicos, de salmos y profetas, para hacer referencia a las grandes estaciones de la historia

${ }^{62}$ Cf. R. E. Brown, El nacimiento del Mesías, 348; R. E. Brown y Otros, María en el Nuevo Testamento, 138ss; E. PeretTo, Voz "Magnificat", 1226.

${ }^{63}$ R. E. Brown y OTROS, María en el Nuevo Testamento, 141. Cf. R. SCHNACKENBURG, La persona de Jesucristo. Reflejada en los cuatro evangelios (Herder, Barcelona 1998) 280-291; G. W. FORBES -

S. D. HARROWER, Raised from Obscurity, 46.

${ }^{64}$ Cf. G. W. ForbeS - S. D. HARrower, Raised from Obscurity, 59-60.

${ }^{65}$ Cf. R. E. Brown y OTRos, María en el Nuevo Testamento, 137.139; N. LOHFInK, Lobgesänge der Armen, 14.

${ }^{66}$ Cf. F. Bovon, El Evangelio según San Lucas I, 136; A.-J. Levine - B. WiTHERINGTON III, The Gospel of Luke, 37; I. RiCHTER REIMER, "Lucas 1-2 bajo una perspectiva feminista”, 33; E. A. JOHNSON, Verdadera hermana nuestra, 301-302. 
de Israe ${ }^{67}$. Entre ellos se pueden mencionar: para el v.49b, 1S 2,1-10 (Lc 1,46b55); Sl 71,19; 44,4ss; 111,9; para el v.50, Sl 103,17; 100,5; 136; para el v.51, Sl 89,11; Is 40,10; 51,9; para el v.52, Si 10,14; Ez 21,31; Job 12,17-19; para el v.53, Sl 107,9; 34,11; Job 22,9; para el v.54, Is 41,8-10 y para el v. 55, Gn 17,7; 2 S 22,51. En la lectura de este estudio se comprende el Magnificat como un himno de acción de gracias, con afinidades textuales importantes al cántico de Ana (1S 2,1-10) y a la oración de David (2S 7). También se admite la evocación de los cánticos de Moisés y de Miriam (Ex 15,1-18.20-21; Nm 12), junto a otros diversos textos, como trasfondo posible ${ }^{68}$. Una investigación detallada sobre las fuentes veterotestamentarias del Magnificat queda pendiente para realizar en otra etapa de estudio.

En cuanto a la estructura hímnica del Magnificat, se puede distinguir una introducción (Lc 1,46b-47), un cuerpo con los motivos de la alabanza (vv.4854a) que puede dividirse en dos estrofas (48-50 y 51-54a), y una breve conclusión (vv.54b-55) ${ }^{69}$. Otros autores siguen una división tripartita en función de observar un triple discurso: espiritual, político y étnico, con tres distintos sujetos ${ }^{70}$. Según R. Brown y otros exégetas, el problema de la estructura está en la segunda estrofa del cuerpo (vv. 48-50), particularmente con el v.48b: "desde ahora me llamarán feliz todas las generaciones", o incluso con el 48a, que se consideran una adición lucana al himno original, lo cual tiene sentido por contener elementos referidos a Mariám ${ }^{71}$. En efecto, el 48b ha sido visto como uno de los versículos capaces de cambiar el sentido de toda la composición y alterar su equilibrio, al interrumpir la secuencia entre la introducción y el segundo motivo mediante la mención de otro personal ${ }^{72}$. La lectura que propone este estudio acepta el agregado lucano del v.48 y reconoce en el himno un motivo personal que incluye otro comunitario, destacándose la unidad del himno en la voz de la cantante. En este sentido, la unidad de lo individual y lo comunitario puede ser percibida con claridad en la ampliación

${ }^{67}$ N. Lohfink, Lobgesänge der Armen, 19. Cf. E. PeretTo, Voz "Magnificat", 1230; F. SCOTT SPENCER, Luke (Eerdmans Publishing Company; Grand Rapids, Michigan 2019) 49ss.

${ }^{68}$ Cf. F. Bovon, El Evangelio según San Lucas I, 123; J. B. GreEN, The Gospel of Luke, 101; E. A. JoHnson, Verdadera hermana nuestra, 300-318; I. Gómez ACEBO, Lucas, 49; C. M. BofF, Mariologia social, 319-320.329 y ss.; G. W. FORBES - S. D. HARROWER, Raised from Obscurity, 50; F. SCOTT SPENCER, Luke, 51.

${ }^{69}$ Cf. N. Lohfink, Lobgesänge der Armen, 14-15; F. BovON, El Evangelio según San Lucas I, 124; J. T. CARroll, Luke, 48-53; M. C. PARSOns, Luke, 41.

${ }_{70}$ Cf. C. M. Boff, Mariologia social, 330ss. El autor sigue la posición de J. DupOnT, "Le Magnificat comme discours sur Dieu", NRT 102 (1980) 321-343. Véase también I. GóMEZ ACEBO, Lucas, 48-49.

${ }^{71}$ Cf. R. E. Brown, El nacimiento del Mesías, 370-371; L. SCHOtTrofF, "Magnificat und die älteste Tradition über Jesus von Nazareth", 303.

${ }^{72}$ Cf. E. PeretTo, Voz “Magnificat”, 1227-1228. 
de motivos de alabanza que tiene lugar en vv.49-50 por medio de una transición de lo personal a lo común, también en la segunda estrofa del cuerpo ${ }^{73}$.

Introducción a la alabanra (46b-47)

46b: la cantante inicia la alabanza

47: alegría de la orante en Dios-salvador

Cuerpo del bimno (48-54a)

Primera estrofa: motivos de alabanza (48-50)

48: Primera fundamentación (personal)

Acción de Dios - humillación de María-sierva: 48a

Anuncio de una futura alabanza a María: 48b

49-50: Segunda fundamentación (personal con ampliación al pueblo)

Acciones de Dios en ella (continúa): 49a

Atributos de Dios y su misericordia con sus fieles: 49b-50

Segunda estrofa: narración antológica (51-54a)

51: Inicio de las acciones de Dios con su pueblo

52-53: Inversión escatológica

Derribo de los poderosos y exaltación de los humildes: 52

Pobres llenados de bienes y ricos despedidos vacíos: 53

54a: Acciones de Dios - Israel-siervo

Conclusión de la oración (54b-55)

54b: Atributo de la misericordia divina

55: Cumplimiento de las promesas

La estructura propuesta se apoya en algunos elementos textuales del himno: 1) ante todo las dos oraciones causales iniciadas con ötı (en vv.48a y 49a) que

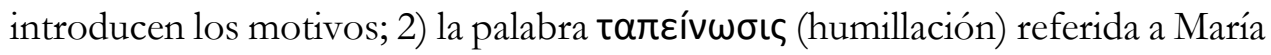
en relación con tåદıvoú (pobres y abajados) en referencia a Israel (en vv.48a y 52), asociadas en ambos casos a una inversión de suertes (v.48 y vv.52-53); 3) la caracterización de María como sierva e Israel como siervo (Lc 1,48a y 54a), aunque los términos griegos utilizados son diferentes; 4) la palabra है $\lambda \varepsilon \circ \varsigma$ (misericordia) que enmarca una cadena de verbos en aoristo al servicio de una memoria de las acciones salvíficas obradas por Dios (en vv.51 y 54b). Con respecto a cómo entender la unidad y las partes dentro de la estructura, N. Lohfink da mucho valor a la segunda estrofa en el conjunto del cántico al señalar que, recién en la ampliación de la fundamentación (v.49b-50) "el Magnificat alcanza su tema propio" 74 . Por cierto, el autor coincide con otros

73 Cf. N. Lohfink, Lobgesänge der Armen, 14-15; I. GÓmeZ ACEBO, Lucas, 49; I. RiChteR REIMER, "Lucas 1-2 bajo una perspectiva feminista", 52; E. A. JOHNSON, Verdadera hermana nuestra, 307.

${ }^{74}$ N. LOHFINK, Lobgesänge der Armen, 15. 
exégetas que reconocen a María el papel de portavoz de Israel en el Magnificat-aunque apenas lo consideran en la visión global de Lucas sobre ella ${ }^{75}$-. Sin embargo, aun reconociendo la extensión e importancia de la narración antológica en la segunda estrofa del cuerpo, esta posición parece atribuir excesiva atención a la ampliación de los motivos de la alabanza en desmedro de los personales presentados en la primera estrofa (48a y 49a). Paradójicamente, al hablar de María como una persona de dimensiones inabarcables, Lohfink parece sólo percibirla en su función de representante de los anawim, sin hacerse eco de su función de portavoz de la primitiva comunidad cristiana como lo recuerdan por ejemplo L. Schottroff e I. Gómez Acebo ${ }^{76}$. En su voz de sierva del Señor, la orante da voz a los anawim de Israel y de la comunidad cristiana naciente de la cual trata el evangelio lucano. El papel atribuido a Mariám posee una función de puente entre Israel, Jesús y la Iglesia. En ella se muestra la continuidad con Israel y la novedad de la salvación de los tiempos mesiánicos ${ }^{77}$.

La referencia al uso del aoristo en el himno y la importancia de su traducción a la hora de interpretarlo resulta fundamental y da lugar a diversas posiciones. Autores como Schottroff, Lohfink, Bovon, Scott Spencer y Navarro Puerto admiten un aoristo gnómico o atemporal -aplicable en todos los tiempos-, aunque se traduce en pasado sobre todo en relación con la cadena de oraciones verbales de vv.51-54 ${ }^{\mathrm{a}}$. Otro grupo, entre quienes se ubica C. Boff siguiendo a Dupont y Lagrange, se inclina por un sentido incoativo - de inicio escatológicocomo posible lectura. Una última opción, seguida por Bock o Gómez Acebo, sostiene más bien un sentido profético, también entendido en clave escatológica $^{78}$. En América Latina, las teologías contextuales han privilegiado -en general- una lectura incoativa o profética del Magnificat, muchas veces con un énfasis excesivo en la dimensión socio-política. En las formulaciones más maduras, en referencia a la doble clave de los acontecimientos del Éxodo y la Pascua, se ha buscado captar e integrar la dimensión socio-histórica del himno

\footnotetext{
75 Véase, por ejemplo, en este sentido a R. E. Brown y OTROS, María en el Nuevo Testamento, 135, 141-143.273.

76 Cf. N. Lohfink, Lobgesänge der Armen, 14; L. SCHOTTROFF, "Magnificat und die älteste Tradition über Jesus von Nazareth”, 301; I. GÓMEZ ACEBO, Lucas, 46.

${ }^{77}$ Cf. R. E. Brown y otros, María en el Nuevo Testamento, 142-143; J. T. Carroll, Luke, 47; C.

D. Yarbrough, "Mary's Magnificat: The Anawim and Church on the Margins", en N. Kollar-M. SHafiQ (eds.), Poverty and Wealth in Judaism, Christianity, and Islam (Palgrave Macmillan, New York 2016) 55-73.

78 Cf. L. SCHOTTROFF, "Magnificat und die älteste Tradition über Jesus von Nazareth", 305; N. LOHFINK, Lobgesänge der Armen, 17-21; F. BOVON, El Evangelio según San Lucas I, 121 123.136-138; F. SCOTT SPENCER, Luke, 53; M. NAVARro Puerto, Los rostros bíblicos de María, 211; C. M. BofF, Mariologia social, 352; D. L. Bock, Luke, 206; I. GÓMEZ ACEBO, Lucas, 49.
} 
y la mesiánico-escatológica, con acento en el amor de Dios por los pobres ${ }^{79}$. En este estudio se admite un aoristo gnómico, aunque no se excluyen otras posibles lecturas.

\section{LA VOZ DE MARIAMM EN EL MAGNIFICAT}

\subsection{Mariám alaba al Señor y se alegra en Dios-su Salvador (introducción)}

El v.46a contiene una breve introducción al Magnificat que, aunque no pertenece al himno como tal, se retoma para visibilizar el sujeto que habla: kai

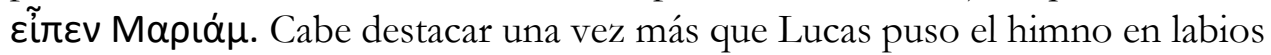
de Mariám. En la escena de la visitación, la voz que ha resonado en el saludo de María a Isabel (v.40), ahora es presentada como canto y alabanza en labios de una sierva que habla por la fuerza del Espíritu que la ha cubierto con su sombra (v.35) ${ }^{80}$. Corresponde también, en este lugar, recordar el nombre dado a ella por Lucas: Mapiá $\mu$, que en hebreo corresponde a Miryam y recuerda su identidad étnica y religiosa ${ }^{81}$. Existe consenso en asociar el canto de Mariám a otras cantoras de Israel: Miriam (Ex 15,1-18.20-21), Debora (Jue 5,1-31), Ana (1S 2,1-10), Judith (Jdt 16,1-17) ${ }^{82}$.

En la narración de la visita, cuando María toma la palabra no es para responder a la pregunta anterior de Isabel $(1,43)$, sino para expresar una alegría incontenible: "la alegría toma la palabra por boca de María" 83 . Con un paralelismo sinonímico y en consonancia con la teología lucana, los vv.46b-47 manifiestan el deseo de alabar por la grandeza del Señor por medio del verbo $\mu \varepsilon \gamma \alpha \lambda u ́ v \omega$ (engrandecer) y de alegrarse en Dios Salvador, para lo cual se

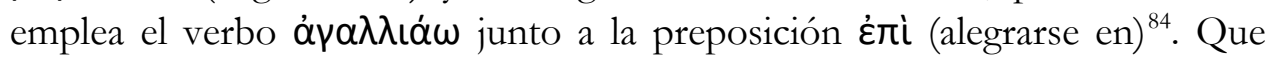

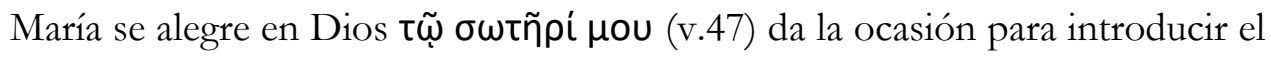

\footnotetext{
${ }^{79}$ Cf. N. LoHFINK, Lobgesänge der Armen, 17; E. A. JoHnSON, Verdadera hermana nuestra, 312; C. M. BofF, Mariologia social, 319-321.351-355; L. BOFF, Mariologia. Interpelações para a vida e para a fé (Editora Vozes; Petrópolis, RJ 2007) 67-103.

${ }^{80}$ Cf. J. B. Green, The Gospel of Luke, 94-95.98ss; M. NAvarro Puerto, Los rostros biblicos de Maria, 211.

${ }^{81}$ Cf. S. CroatTo, “La «hija de Sión» en Lc 1-2", 19-20; D. Good, "What does it mean to call Mary Mariam?”, en A.-J. Levine (ed.), A Feminist Companion to Mariology, 99-106, 99.

82 Cf. E. A. Johnson, Verdadera hermana nuestra, 306; C. M. Boff, Mariologia social, 335; I. GÓmez ACEBO, Lucas, 49; G. W. ForbeS - S. D. HARrower, Raised from Obscurity, 52; A.-J. LEVINE - B. Witherington III, The Gospel of Luke, 39-40; F. SCOTT SPENCER, Luke, 51; M. WOLTER, The Gospel according to Luke I (1-9:50) (Baylor University Press, Mohr Siebeck 2017) 91.

${ }^{83}$ L. Alonso Schökel- J. Mateos, Salmos y Cánticos del Breviario, 474. Cf. F. Bovon, El Evangelio según San Lucas I 129; F. SCOTT SPENCER, Luke, 52-53.

${ }^{84}$ Cf. F. Bovon, El Evangelio según San Lucas I, 130.
} 
nombre divino owtńp (Salvador), por vez primera en el evangelio y la única que se atribuye $\operatorname{Dios}^{85}$. La alegría de la salvación, ya presente en v.14 (en el anuncio sobre Juan, el Bautista), v.28 (en el anuncio sobre Jesús, el Mesías) y v.44 (en la visitación), se reitera en el Magnificat creando una atmósfera muy típica, de tenor emocional ${ }^{86}$. En vv. 46b-47, se destaca el trasfondo de dos salmos, Sl 34,3 y 35,9, de Ha 3,18 y del inicio del canto de Ana: "Mi corazón se regocija en el Señor, tengo la frente erguida gracias a mi Dios. Mi boca se ríe de mis enemigos porque tu salvación me ha llenado de alegría" (1S 2,1). Queda de manifiesto que el tema del himno es Dios salvador, asociado en Lucas a la historia de la salvación con alcance universal. El tenor teológico del himno enlaza, a continuación, la salvación y la misericordia expresada con poder en las $\mu \varepsilon \gamma \alpha \dot{\alpha} \lambda \alpha$ (v.49). En tanto, la misericordia se presenta bajo la perspectiva de las acciones y no tanto como atributo ${ }^{87}$.

\subsection{Los motivos del canto de alabanza en labios de Mariám (primera estrofa)}

Con el v.48a se enuncia la primera fundamentación -personal- de la acción de gracias y comienza el cuerpo del himno ${ }^{88}$. En ella se alaba a Dios por su mirada, porque pone sus ojos sobre la humillación de su sierva. Este verbo

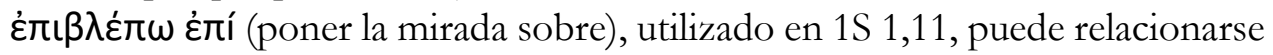

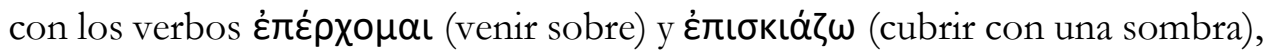
usados por Lucas en 1,35 para indicar una continuidad con la presencia de Dios manifestada en la nube de su gloria sobre la tienda del desierto (Ex 40,34-35) ${ }^{89}$. Las exégetas feministas y otras/os subrayan que estos verbos no se han de entender en un sentido sexual, sino como presencia que faculta y protege como es en el caso de David (1S 16,13) y como expresión de salvación y elección ${ }^{90}$. Esta mirada puesta sobre Mariám expresa, en definitiva, un plan de Dios sobre ella, que no es otro que el plan de una salvación universal.

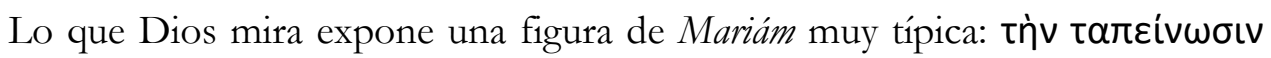

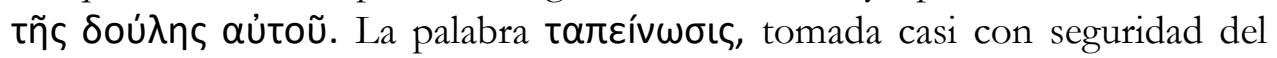
relato de Ana (1S 1,11), ha de entenderse como humillación, esterilidad o pobreza y no meramente como condición humilde, para no perderse la referencia a la situación histórica concreta. En el caso de Ana -como en el de Isabel- la humillación personal pasa por una situación de esterilidad y la espera

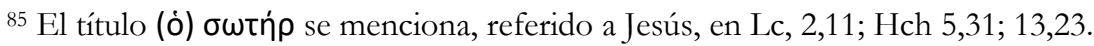

${ }^{86}$ Cf. F. SCOTT SPENCER, Luke, 52-53.

${ }^{87}$ Cf. F. Scott Spencer, Luke, 50. El autor establece una relación entre el Magnificat y el S1 136.

${ }^{88}$ Cf. R. E. Brown, El nacimiento del Mesías, 343.

89 Cf. S. CrontTo, “La «hija de Sión» en Lc 1-2”, 26.

${ }^{90}$ Cf. E. A. Johnson, Verdadera hermana nuestra, 292-295; I. Richter ReIMER, "Lucas 1-2 bajo una perspectiva feminista", 49-50.
} 
de un hijo, mientras en el caso de Mariám, en general, se piensa en una situación social y religiosa. Sin embargo, la lectura feminista ha reconocido en este $\tau \alpha \pi \varepsilon i ́ v \omega \sigma \iota \varsigma$ un sentido mucho más concreto, considerando el relato de anunciación del evangelio de Mateo: "José, su esposo, que era un hombre justo y no quería denunciarla públicamente, resolvió abandonarla en secreto" (Mt $1,19)^{91}$. De acuerdo con este testimonio, la humillación de Mariám consistía en que su esposo la consideraba una adúltera y, por ser justo, había decidido repudiarla en silencio hasta conocer el plan de Dios.

En el caso de la esposa de José -como en la historia de Ana- esta

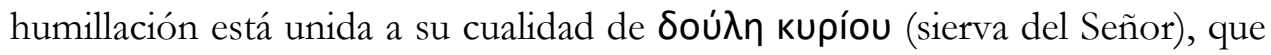
contrasta con el contexto histórico de un sistema como el romano en el cual se esclaviza $^{92}$. En el relato lucano, luego de recibir el anuncio del ángel Gabriel, Mariám toma la decisión de ponerse al servicio de un Dios que libera y excluye a otros señores. Responde dándose la auto-designación personal de $\delta o u ́ \lambda \eta$ kupíou (v.38), que vuelve a repetirse al expresar su motivo de alabanza (v.48a). La presencia de esta fórmula en el texto de Lucas, siendo infrecuente su uso en femenino en el Antiguo Testamento, inaugura una apertura de género para otras mujeres en el Nuevo Testamento ${ }^{93}$. A la humillación descripta en el v.48a, que puede entenderse a causa de un embarazo que no es fruto de la intervención de su esposo, el himno agrega el anuncio de una bienaventuranza futura (v.48b) que evoca la anterior pronunciada por Isabel (v.45). En ambos casos, la alabanza tiene por objeto la fe de Mariám en el cumplimiento de lo anunciado: la maternidad mesiánica, poniendo el acento no en la maternidad sino en el Mesías como también queda expresado en el episodio de Lc 11,2728. Este doble macarismo, que anticipa las bienaventuranzas (Lc 6,20-23), pone de manifiesto un elemento central de la teología del Magnificat, al mismo tiempo que completa junto al v.48a la descripción de una inversión de destino: si el v.48a primero afirma la humillación de la sierva del Señor, luego propone su

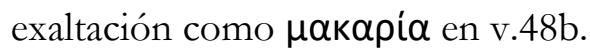

Los vv.49-50 pueden considerarse juntos porque dan paso al enunciado de una nueva fundamentación personal de la alabanza (v.49) y a su ampliación comunitaria (v.50). La vOz de quien ha experimentado, personalmente, la inversión de suertes, ahora inicia su alabanza como representante de su pueblo. De este modo, la que pronuncia su alabanza incluye la acción de gracias de su pueblo, mostrando la inseparabilidad entre lo personal y lo comunitario, lo

\footnotetext{
${ }^{91}$ Cf. L. SCHOTTROFF, Lydia's Impatient Sisters, 180ss; M. NAVARRO PUERTO, Los rostros bíblicos de María, 155ss. Véase también R. E. BROwn, El nacimiento del Mesias, 126 (sobre la idea convincente de que José considerara a María como adúltera).

${ }^{2}$ Cf. I. Richter ReIMER, “Lucas 1-2 bajo una perspectiva feminista”, 51.

${ }^{93}$ Cf. I. Gómez Acebo, Lucas, 42.
} 
privado y lo público ${ }^{94}$. El centro recae, primero, en la profecía pronunciada por

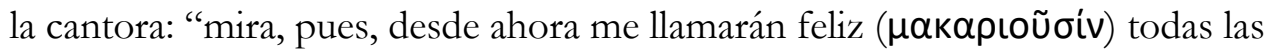
generaciones" (48b). Su fe y su asentimiento libre hicieron posible su exaltación como bienaventurada, a pesar de la humillación que supuso la sospecha de adulterio; su pertenencia al pueblo de Israel, también humillado y oprimido, la hace solidaria en su canto que hace memoria de la acción divina. Por esta razón, los vv.49-50 mencionan los atributos divinos: poder, santidad y misericordia, destacándose este último.

La primera estrofa del himno expone los motivos de la acción de gracias: la acción de Dios en lo personal (vv.48a y 49a) se integra con la alabanza por sus obras en la historia de Israel (v.50), enlazándose la manifestación del obrar divino en el pasado con las futuras generaciones que reconocerán la fe de la sierva de la nueva alianza (v.50 y 48b). Se muestra, de este modo, que el tenor temporal del himno abarca un arco cósmico: Mariám canta a Dios y con ella, en coro, lo hacen ellos e, incluso, ¡nosotros! ${ }^{95}$

\subsection{Mariám, portavoz de las acciones salvíficas de Dios (segunda estrofa)}

El cuerpo del himno se completa con una segunda estrofa concentrada en la acción de gracias por las obras salvíficas de Dios en la historia de Israel. La

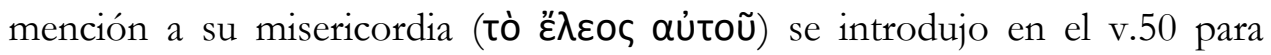
enmarcar la fundamentación de la alabanza comunitaria y se despliega desde el v.51 hasta v.54b que retoma el mismo motivo: acordándose de la misericordia, sobre el trasfondo del S1 98,3. Los siete verbos en aoristo, que eslabonan los vv.51-54a, estructuran la memoria de la intervención salvífica de Dios y se asocian aproximadamente a las principales estaciones de la historia de Israel ${ }^{96}$. Dios es el sujeto de todos los verbos del cuerpo del himno, excepto en el caso de 48b. Lo que Dios hizo en Mariám es el punto final de lo que hizo en su pueblo: la historia de Israel es la historia de su pueblo y en ella se resume toda la historia de Israel. El final del poema (vv.54b-55) revela que estas acciones salvíficas tienen como destinatario a Israel y no a la humanidad en general. Por el uso del aoristo gnómico, ellas pueden referirse tanto al pasado como al modo habitual de la acción de Dios, aunque por el carácter antológico del poema deben traducirse en pasado ${ }^{97}$. La figura de Mariám manifestada por medio del himno puesto en sus labios se llena de novedad: ella se presenta ante todo como portavoz de Israel, con quien comparte la condición de sierva/o: 'lopaǹ $\lambda$

\footnotetext{
94 Cf. E. A. Johnson, Verdadera hermana nuestra, 307.

95 Cf. L. SCHOtTROFF, "Magnificat und die älteste Tradition über Jesus von Nazareth", 305; F. SCOTt SPENCER, Luke, 48.53; M. NAVARro Puerto, Los rostros bíblicos de María, 211-212. ${ }^{96}$ Cf. N. Lohfink, Lobgesänge der Armen, 14-15.19-21; J. B. GreEn, The Gospel of Luke, 100.

${ }^{97}$ Cf. N. LoHFINK, Lobgesänge der Armen, 19.
} 


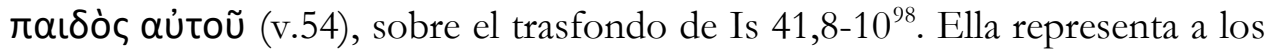
anawim y por eso realiza su vocación como portavoz de Israel e integrante de la comunidad naciente en torno a Jesús. Asimismo, ella es propuesta por Lucas como intérprete de la historia de su pueblo en las Escrituras y como la primera en vincular esta historia con las acciones de Dios en su tiempo presente ${ }^{99}$. El himno expresa el tránsito del Antiguo al Nuevo Testamento, el paso de Israel a la Iglesia, el traslado del arca hasta la última estación que es el mismo cuerpo de la madre del Mesías. En el Magnificat resuena la voz de una matriarca cantando su alabanza en nombre de los patriarcas y su descendencia (v.55) ${ }^{100}$.

El núcleo duro de la segunda estrofa está conformado por la "inversión escatológica" o "reversión de poder y fortuna", cuya escenificación se realiza en los vv.52-53 ${ }^{101}$. La formulación de estos versículos se inspira casi con seguridad en el Cántico de Ana (2S 2,5), aunque también se encuentra un lenguaje semejante en las tradiciones davídicas ${ }^{102}$. Este cambio de destinos pone de relieve el tenor social del himno: los poderosos dan paso a los humillados y los hambrientos suceden a los satisfechos, lo cual es perfectamente compatible con el tenor teológico del himno ${ }^{103}$. Parece importante recordar que el mensaje central del cántico es Dios y su acción salvífica dirigida a los pobres. La presencia del elemento social o político no significa que se trate de una propuesta reductiva, y una crítica a una tal lectura del himno -sea esta espiritualista o politizada- debe afirmar que el Magnificat es, a la vez, históricamente relevante y teológicamente determinante ${ }^{104}$. La inversión de suertes manifiesta el advenimiento de la salvación en la historia, tanto en el pasado como en el futuro, como transformación de la realidad socioeconómica y espiritual de los humillados. Una lectura solo social o espiritual del Magnificat se evidencia como parcial, puesto que ambas dimensiones del himno se presentan de forma inseparable ${ }^{105}$. En su humillación personal, María queda asociada a los tareıvoúc (pobres y abajados), a quienes el Señor también mira y ambos son agraciados con un

\footnotetext{
${ }^{98}$ Cf. R. E. Brown y Otros, María en el Nuevo Testamento, $141 \mathrm{ss}$.

99 Cf. M. Navarro Puerto, Los rostros bíblicos de María, 211-212; G. W. Forbes - S. D. HARROWER, Raised from Obscurity, 51.

100 Cf. I. Richter Reimer, "María en los evangelios sinópticos", 43.

${ }^{101}$ Cf. A.-J. LeVine - B. Witherington III, The Gospel of Luke, 42-43; J. T. CARroll, Luke, 47; C. D. Yarbrough, "Mary's Magnificat: The Anawim and Church on the Margins", 5658.

102 Cf. S. Croatto, “La «hija de Sión» en Lc 1-2", 24ss.

103 Cf. F. SCOTT SPEnCER, Luke, 49-50.54; M. C. PARsons, Luke, 41.

104 C. M. BofF, Mariologia social, 320.

105 Cf. C. M. Boff, Mariologia social, 316-319; F. SCOTt SPENCER, Luke, 49-54.
} 
cambio de suertes, el cual encuentra su mejor expresión en el macarismo. Se trata de una verdadera revolución centrada en el reino de Dios ${ }^{106}$.

\subsection{La voz de la profetisa Mariám en solidaridad con las mujeres}

2.4.1. El "canto común" de Isabel y Mariám

Los exégetas de la corriente masculina-mayoritaria no dudan en afirmar que Lucas, al poner el Magnificat en labios de Mariám, la hace portavoz del tema de la inversión (Lc 1,52-53). En el clásico estudio ecuménico María en el Nuevo Testamento, ellos afirman: "Si, por la aceptación de la palabra de Dios, Jesús $(1,38.45)$, María es la primera discípula cristiana, primera en reunir las cualidades exigidas por la familia escatológica de Jesús $(8,21)$, ella proclama ahora por anticipado el evangelio" 107 . Se trata de una aseveración importante, pero que -en esa obra- tiene escasa relevancia en lo que se refiere a la figura global de María en el tercer evangelio ${ }^{108}$. En este sentido, las cartografías de los estudios feministas iniciadas en este artículo permiten recuperar la figura profética de Mariám en solidaridad con otras mujeres.

Un primer elemento de esta recuperación consiste en comprender a la cantora del Magnificat en solidaridad con su prima Isabel. La secuencia de la historia de Isabel en el anuncio sobre el Bautista (Lc 1,5-25), la historia vocacional de Mariám (1,26-38) y el encuentro entre ambas (39-56), da una base textual para plantear tal solidaridad. Cada uno de estos episodios apuntan al anuncio y/o al nacimiento de Jesús. También la profecía de Ana (2,36-38). Como señala Barbara E. Reid, "las proclamaciones proféticas de Isabel, María y Ana -en las narrativas lucanas de la infancia- preparan el camino para el ministerio profético de Jesús e introducen los temas teológicos prominentes de este evangelio" "109. Según Lucas, el mismo Jesús es caracterizado como זрофńtns (Lc 4,24), a semejanza de Moisés y Elías. También, en un pasaje exclusivamente lucano, Jesús se define a sí mismo como profeta y vincula su destino de muerte en Jerusalén (13,33). En conjunto, el evangelista presenta a Jesús profeta como "portavoz de Dios" (Ex 4,15-16), que transmite la palabra divina con plena autoridad (Lc 4,32.43; 5,$1 ; \mathrm{Hch} 10,36)^{110}$. Se puede pensar que las figuras de los ciclos de anuncio y nacimiento preparan la de Jesús como

\footnotetext{
106 Cf. N. LOHFINK, Lobgesänge der Armen, 16; C. JANSSEN - R. LAMB, "Das Evangelium nach Lukas", 519-520; A.-J. LEVINE - B. WiTHERINGTON III, The Gospel of Luke, 42-43.

${ }^{107}$ R. E. Brown y OTROS, María en el Nuevo Testamento, 141. Cf. R. E. Brown, El nacimiento del Mesias, 356-357; R. E. Brown y OTROs, María en el Nuevo Testamento, 135.137; J. A. FITZMYER, El evangelio segun San Lucas II, 135-136.

108 Cf. R. E. BRown y OTROS, María en el Nuevo Testamento, 273-275.

109 B. E. REID, "An Overture to the Gospel of Luke”, 434.

${ }^{110}$ Cf. J. A. FitZMYER, El evangelio según San Lucas I, 357-361; R. SCHNACKENBURG, La persona de Jesucristo, 203ss; B. E. REID, "An Overture to the Gospel of Luke”, 433.
} 
Ěxpı ćv (Ungido) Lc 4,16-30, que arroja su luz sobre la totalidad del evangelio mostrando el nexo de Jesús con el Espíritu ${ }^{111}$.

En el anuncio sobre Juan, el Bautista, la historia de Zacarías e Isabel introduce una situación de humillación -no tenían hijos- que sirve para caracterizar la experiencia de opresión del pueblo judío de entonces. La degradación se aplica en concreto a la esterilidad de Isabel y al hecho de que ambos eran ancianos. Zacarías, que era sacerdote, recibe el anuncio del embarazo de su esposa en el templo, del nacimiento de un hijo que será motivo de alegría y estará "lleno del Espíritu Santo desde el seno de su madre" (Lc 1,15). El texto no da muchos detalles, pero agrega que, poco después, Isabel concibió un hijo y pensaba: "Esto es lo que el Señor ha hecho por mí, cuando decidió librarme de lo que me avergonzaba" (Lc 1,23). Lo que se pone de manifiesto en estas palabras es una subversión de la discriminación. Así, la esterilidad y la ancianidad como motivos de humillación son anuladas por la acción de Dios que posibilita el embarazo de Isabel ${ }^{112}$.

En la visita a Isabel, se marcan algunos elementos que establecen una continuidad: Mariám, con su entrada y la voz de su saludo, se muestra como portadora del Espíritu, del cual queda llena Isabel; la alegría del niño por nacer; y las alabanzas dirigidas a Mariám por parte de Isabel. Y otros que señalan discontinuidades: la escena tiene lugar en una casa -no en el templo-; no hay voces masculinas -ni José, ni Zacarías-; María dirige su alabanza a Dios, aunque la visita se manifiesta como un signo de Dios para Isabel. Lo que reluce en esta escena, en medio de lo cotidiano, es la salvación en los cuerpos grávidos de dos mujeres solidarias que se fortalecen una a la otra en el encuentro mutuo $^{113}$ : Isabel, retratada por Lucas utilizando los rasgos de la tradición de la matriarca estéril según la Biblia hebrea, en relación con Sara, Rebeca, Raquel, la madre de Sansón y Ana, además del símbolo de la Jerusalén estéril ${ }^{114}$. Mariám, en esta escena, es alabada como "bendita entre las mujeres" (Lc 1,42), es decir, junto a otras mujeres (Jue 5,24 y Jdt 13,18). Desde una perspectiva feminista, la revolución puede quedar expresada así: "a pesar de un contexto literario absolutamente androcéntrico, esta historia se cuenta de modo enteramente ginecéntrico" ${ }^{\prime 15}$. Si bien desde el punto de vista narrativo a cada mujer le corresponde un canto propio (Lc 1,42-45; 46b-55), las autoras feministas han

${ }^{111}$ La idea de $\check{\chi} \chi \rho ı \varepsilon ́ v$ se manifiesta en Lc 2,11.26; 3,15; 4,41 y 9,20. Cf. R. SCHNACKENBURG, La persona de Jesucristo, 203-229.

112 Cf. I. RiCHTER REIMER, "Lucas 1-2 bajo una perspectiva feminista", 35-43.

113 Cf. I. RiChter Reimer, "Lucas 1-2 bajo una perspectiva feminista", 33; E. A. JoHnson,

Verdadera hermana nuestra, 300ss.

114 Cf. E. A. Johnson, Verdadera hermana nuestra, 303.

115 E. A. JOHNSON, Verdadera hermana nuestra, 302. La autora cita a L. SCHOTTROFF, Lydia's Impatient Sisters, 191ss. 
resaltado la solidaridad entre Isabel y Mariám con la imagen de un "canto común"116.

\subsubsection{En la tradición de mujeres humilladas y exaltadas por Dios}

La solidaridad entre mujeres que irradian tanto las historias personales de Isabel y Mariám como el encuentro entre ambas, puede situarse también en el horizonte de una tradición judía de mujeres humilladas y exaltadas por Dios, según las perspectivas abiertas por Luise Schottroff. Gracias al aporte de la historia social, existe la posibilidad de explorar la opresión de las mujeres y sus prácticas de liberación a partir de esta tradición bíblica, lo cual da cuenta de un segundo elemento para estas cartografías de exégesis feminista ${ }^{117}$. En este sentido, la autora ha propuesto una lectura del relato lucano de infancia en conexión con otros pasajes -sobre todo Mt 1,19 y Jn 7,53-8,11- que se inscriben en la amplia tradición narrativa que habla de la liberación de las mujeres humilladas como exaltación de los humildes ${ }^{118}$.

Como ya fue señalado, la humillación de Mariám mencionada en el Magnificat (Lc 1,48a) no puede ser entendida solo en términos generales, sociales y religiosos, sino en el marco de su situación esponsal de la cual el relato mateano (Mt 1,19) puede aportar información. Así como en la genealogía del relato de infancia de Mateo se menciona a un grupo de mujeres que han dejado descendencia a través de relaciones extramatrimoniales -tal es el caso de Tamar, Rahab, Rut y Betsabé, la mujer de Urías-, para explicar lo extraordinario de la situación de María, llamada a ser madre del Mesías virginalmente, algo semejante sucede en el relato lucano ${ }^{119}$. En él, la inversión de destino en la vida de Isabel como anciana estéril prepara otra inversión, de alguna manera superior por vincularse al Mesías, que tiene lugar en la vida de Mariám como novia desposada. Si la vergüenza que degrada a Isabel viene de su esterilidad y ancianidad, la que vive su parienta se relaciona con un embarazo que acontece al margen de la ley (Dt 22,13-21): "la decisión del repudio implica un juicio y, tal vez, una acusación implícita: María es una adúltera" ${ }^{120}$.

Para poder dimensionar la situación de María -incluso la de Isabel-, sobre la cual el narrador omite detalles que interrogan al lector y la lectora, Luise Schottroff introduce la lectura de la mujer adúltera en Jn 7,53-8,11, por tratarse de la historia de una mujer humillada y exaltada por Dios, en este caso Jesús. Junto a los textos, la autora plantea las cuestiones socio-históricas: según la

\footnotetext{
116 C. JANSSEN - R. LAMB, "Das Evangelium nach Lukas", 519.

117 Cf. L. SCHOTTROFF, Lydia's Impatient Sisters, 46ss.

118 Cf. L. SCHOTTROFF, Lydia's Impatient Sisters, 177ss.

${ }^{119}$ Cf. R. E. Brown, El nacimiento del Mesías, 65-69; M. NAvarro Puerto, Los rostros bíblicos de María, 144-147.

120 M. Navarro Puerto, Los rostros bíblicos de María, 160.
} 
legislación matrimonial patriarcal de la tradición judía, el adulterio era considerado un crimen capital que ofendía el derecho del marido a poseer la sexualidad de su mujer y merecía como castigo la lapidación pública y representaba, por lo tanto, un destino de muerte ${ }^{121}$. En el pasaje del cuarto evangelio, los acusadores de la mujer adúltera piden participación a Jesús: él no se opone a la ley, pero redimensiona el adulterio ubicándolo a la altura de otras faltas y se pone del lado de la mujer humillada. Desde el punto de vista de la historia de la interpretación, la autora también señala que la tradición patriarcal oscurece la sustancia liberadora de la tradición bíblica de mujeres exaltadas y humilladas y busca reconstruir la historia de la adúltera como persona ${ }^{122}$. Con respecto a las perspectivas feministas resultantes, L. Schottroff reflexiona sobre la humillación de las mujeres pobres que puede incluir la bumillación sexual. Según la autora, la historia de María representa un destino de aflicción y la profecía de la opción de Dios por los pobres y por las mujeres ${ }^{123}$.

La solidaridad de Mariám con las mujeres humilladas y exaltadas de Israel merece que se prolongue la indagación en otros estudios. En primer lugar, su parentesco con otras mujeres cantoras que han desempeñado una función profética. Su condición de humillada la ubica junto a la profetisa Ana, una mujer sin hijos que sufre en una sociedad patriarcal, con quien comparte además la identidad de sierva del Señor $(1 S$ 1,11). Así como Ana representó la situación de Israel en su transición a los tiempos de la monarquía, Mariám representa el tránsito de Israel a los tiempos mesiánicos y anuncia una reversión de destinos que denuncia el orden injusto y anuncia la intervención poderosa de $\operatorname{Dios}^{124}$. La referencia a la profetisa Miriam también parece estar evocada en los relatos lucanos, en razón del nombre asignado a la sierva de Dios y -de forma implícita- por la cercanía entre los acontecimientos salvíficos de Éxodo y Pascua ${ }^{125}$. Una lectura de ambas figuras pone de manifiesto una diferencia notable entre ellas: Miriam canta de forma breve y a la sombra de Moisés, mientras que, en la narrativa lucana, Mariám canta sin haber una figura masculina autoritativa ${ }^{126}$. La solidaridad de María con otras matriarcas de Israel, expresada

121 Cf. L. SCHOTTROFF, Lydia's Impatient Sisters, 181 ss.

122 Cf. L. SCHOTTROFF, Lydia's Impatient Sisters, $196 \mathrm{ss.}$

123 Cf. L. SCHOTTROFF, Lydia's Impatient Sisters, 199.

124 Cf. I. MÜLlner, "Die Samuelbücher", en L. SChOtTroff - M.-TH. WaCKER (eds.), Kompendium Feministische Bibelauslegung, 114-129; L. BOFF, Mariologia, 71-84.

125 Cf. J. B. Green, The Gospel of Luke, 101; E. A. Johnson, Verdadera hermana nuestra, 300-301; C. M. BofF, Mariologia social, 319ss.

126 Cf. G. W. FORBES - S. D. HARROWER, Raised from Obscurity, 52. Se recuerda, por otra parte, que las exégetas feministas discuten quién canta en Ex 15. Cf. M. GARCIA BACHMANN, "Para entender el papel de la profetisa Miriam. La construcción simbólica del castigo en Números 11-12", en V. R. AZCUY - N. E. BEDFORD - M. GARCIA BACHMANn, Teología feminista a tres 
en el "bendita entre las mujeres" $(1,42)$, ayuda a ubicar en el valor de su talla: no es la única, pero tampoco una más...

\section{REFLEXIONES FINALES: LAS ÚLTIMAS SERÁN LAS PRIMERAS}

Al poner el Magnificat en labios de Mariám, Lucas la propone como primera cantora del evangelio -antes que Zacarías y Simeón- y como auténtica portavoz de Dios. Como ha señalado E. A. Johnson, "siendo [este himno] el pasaje más largo puesto en boca de una mujer en el Nuevo Testamento, representa lo más que una mujer alcanza a decir" ${ }^{127}$. Como otros profetas y profetisas de Israel, ella canta las $\mu \varepsilon \gamma \alpha \dot{\lambda} \lambda \alpha$ de la salvación, las acciones de la misericordia divina en su vida y la de su pueblo ${ }^{128}$. En la voz de su canto se une la alabanza por la reversión de destino obrada en su propia historia y la de Israel. Este canto es una acción de gracias por la intervención de Dios, un signo de su reinado, opuesto al de Herodes, vasallo del emperador Augusto ${ }^{129}$. Si en el anuncio sobre Jesús, Isabel es presentada a Mariám como signo de la acción de Dios; en la visitación, ésta se vuelve signo para Isabel y las futuras generaciones $(1,45.48 b)^{130}$.

La lectura feminista del Magnificat puede abrir nuevas perspectivas para reencontrar a María, sobre todo para las mujeres que esperan ver en ella, junto a su Hijo, un signo de libertad y liberación ${ }^{131}$. La tarea de la exégesis feminista continúa, en diálogo con otros y otras exégetas. Se podría retomar, por ejemplo, la cuestión del lugar de las mujeres en la obra lucana y su relación con mariología y la eclesiología del tercer evangelio. Y también, en este mismo contexto, el planteo sobre el bloque de Lc 1,5-2,52 como posible clave hermenéutica de la doble obra de Lucas $^{132}$. El carisma profético de Isabel, María y Ana en los ciclos de anuncio y nacimiento proyecta una luz potente sobre toda la eclesiología lucana -no exenta de tensiones como lo muestran algunos estudios pioneros- y puede representar un punto de referencia

\footnotetext{
voces (Ediciones Universidad Alberto Hurtado, Santiago 2016) 65-102; B. E. REID, “An Overture to the Gospel of Luke", 429.

${ }^{127}$ E. A. JohnSON, Verdadera hermana nuestra, 305.

${ }^{128}$ Cf. L. SCHOTTROFF, "Magnificat und die älteste Tradition über Jesus von Nazareth", 300; F. SCOTT SPENCER, Luke, 50-51.

${ }^{129}$ Cf. I. RiCHTER REIMER, "Lucas 1-2 bajo una perspectiva feminista”, 48; F. SCOTTT SPENCER, Luke, 54.

${ }^{130}$ Cf. M. Navarro Puerto, Los rostros bíblicos de María, 210.

131 V. R. AzCUY, "Reencontrar a María como modelo. Interpelación feminista a la mariología actual", Proyecto 39 (2001) 163-185; C. M. BOFF, Mariologia social, 311ss.

132 Cf. L. Schottroff, Lydia's Impatient Sisters, 180-181; C. JANSSEN - R. LAMB, "Das Evangelium nach Lukas", 517 y 519.
} 
fundamental para evitar lecturas en complicidad con una visión androcéntrica ${ }^{133}$.

Las perspectivas abiertas por el presente estudio indican que la voz de Mariám en este cántico, en los umbrales del cristianismo primitivo, augura una profunda revolución en tiempos de dominación masculina. La inversión escatológica anunciada en el Magnificat se realiza en la misma vida de una mujer que canta como representante de Israel y de la Iglesia naciente, como profetisa y discípula (cf. Lc 1,26-56; 11,27-28). Cabe esperar que en las futuras generaciones, se verifique cada vez más una reversión de destinos que haga posible que las últimas sean las primeras (Lc 13.30), como lo ha expresado Dorothee Sölle reformulando el Magnificat para este tiempo: "los rostros vacíos de las mujeres, se llenan de vida"134.

133 Cf. I. Richter ReImer, Women in the Acts of the Apostles, XV-XX; M. Perroni, "Discípulas, pero no apóstoles en la obra de Lucas", 184-195.

134 D. SÖLLE, "Meditation über Lukas 1", en Die revolutionäre Geduld: Gedichte (Schritte 26; Fietkau Verlag, Berlin 1974) 26. La cita está tomada de F. BOvON, El Evangelio según San Lucas I, 139-140. 